\title{
ROBBERFLIES OF THE GENUS ASILUS.*
}

\author{
James S. Hine.
}

The insects of this genus together with a large number of others belong to the Asilidae which is a family of Diptera commonly called robberflies because of their predaceous habits in the adult stage. These habits usually lead to beneficial results but none of the species are known to show any indication that they prefer particular food. They take all kinds of insects that inhabit like places with them, and have the habit of alighting on a leaf or a stone, a log or other object, or even on the bare ground to wait for some unfortunate insect of almost any order to appear, when they leave their perch and, like a hawk, pounce upon the chosen victim and at once introduce their piercing mouthparts and suck away its life blood. Occasionally some observer finds certain species to be injurious on account of feeding on beneficial species, and it is no more than likely that all of the members of the family do some harm. Riley has stated that one of the larger robberflies may be very destructive to honey bees, and frequently one may see one or another of the flies with a parasitic insect in possession. Such habits furnish much of interest to the observer in the field, and the student who is in search of a subject full of sentiment will do well in making a selection here.

So far as known the larvae are predaceous and are found in dry ground. They work beneath the surface and seek out such available food as these situations offer. Two larvae of Asilus sericeus Say, were taken April 3, while spading a garden. They were located about six inches below the surface of the ground, color white, naked with the exception of a very few brown hairs scattered over the body, general form cylindrical, or only slightly compressed; in appearance much like what in general pass under the common name of grubs. Total length when full grown 20 millimeters. The pupa stage was reached May 25, and the adult appeared June 8.

The various species of the family are mostly large insects, but have been neglected more or less in America, some of the genera as yet not having received the attention of specialists beyond the

* Contributions from the Department of Zoology and Entomology of the Ohio State University, No. 32. 
description of such species as have been brought to their attention for names. There is in the collections of the country, therefore, a quantity of undetermined material and not a few undescribed species which are a hindrance to investigators as well as to the painstaking amateurs whose ideals are to have all specimens named and grouped in reference to some particular system under a series of neatly written labels.

The genus here considered is classified in the Asilinae, one of the four subfamilies into which the family is divided in North America. In the Asilinae the species are of medium to large size, long and slender form and black, yellowish, brownish or gray color, with a close general resemblance throughout the group. The antennae each are composed of three segments of which the first is longer than the second, and the third longest of all; the latter segment at its apex bears a long style or arista composed of two segments of which the first is very short. In the wing the marginal cell is always closed, as are the fourth posterior and anal cells, and there are either two or three submarginal cells of different lengths. The members of the genus Asilus are typical of the subfamily, the antennal arista is naked, the posterior branch of the third vein reaches the margin of the wing beyond its apex, there are two submarginal cells in all cases and the veins which close the discal and first posterior cells are not parallel.

Ever since Loew monographed the European robberflies in I848 and divided the genus Asilus of Linnæus into groups with separate names, students have been at variance as to whether or not Loew's names should be considered as genera. In Dipternfauna Sudafrica's issued in 1860 , Loew himself raised his names to generic rank, but Schiner, one of the foremost students of Diptera, writing at about the same date considered Asilus in the wide sense. Later European students in the main have been inclined to follow Loew as have some Americans. Lately, however, there is a tendency to drop Loew's names and include all of the species concerned in the genus Asilus, thus following Schiner's arrangement. Thus Pandelle, an European, writing as late as I905, and Williston of this country, in his revised edition of North American Diptera, published in I908, have made it plain that they prefer the latter. Personal inquiry brings out the fact that nearly all of the prominent dipterologists of the United States are ready to accept Williston's viervs in the matter. 
In his Manual Williston says that "In general the subdivisions of the old genus Asilus are very vague and hard to define, and many of them are doubtfully entitled to recognition. At the most, few, if any, of them are based upon real generic characters and the names are only useful as aids in the determination of the numerous forms."

Lundbeck, in his Diptera Danica I908, II, 53, gives what argument there is for the other side when he says of these names that "Though it cannot be denied that as genera they are far more closely allied and taken in a narrower sense than genera are commonly, I shall yet retain them, chiefly because they are generally in use and at all events give valuable hints about the natural classification of the species."

Before beginning the study of the species considered in this paper, I procured representative specimens of Loew's groups from Europe by exchanging with Dr. M. Bezzi and others, and with these for reference have undertaken to place the North American species. The list offered below indicates the success achieved, but as may be noted some of the species do not fall naturally into any of the groups and even in some cases where a decision appears to have been reached, there are difficulties in the way of a perfectly satisfactory conclusion. It may be mentioned also that Dr. Bezzi encountered some difficulty in placing the Nearctic species, for at the end of the Asilinae in the recent Catalogue of Palearctic Diptera is a list of no less than twenty-nine species, which from the evidence cannot be placed in the so-called genera, but are given as falling under the genus Asilus in the wide sense.

By giving only Asilus generic rank and using the other names, that often have been considered as genera, simply as names of groups, some questions in priority come up for solution. Since Europeans were the first to arrange their species in reference to Loew's classification, the proper procedure would be for them to be the first to discard it. As it is students in America have described many of their species on the ground that Loew's names were valid generic terms, using the same specific name in two or more genera. If these names are considered as genera in Europe, as is the case in the recent catalogue mentioned above, and only as groups of one genus in America, a student in the latter country hardly knows what is the proper disposition of the synonymy question in his fauna. With these facts confronting me, I do 
not know of a better way of accepting Williston's views on the extent of the genus Asilus than to restrict it only by the description I have given above, and this would also agree with Schiner's views so far as European species are concerned. Having reached this conclusion I have worked out the syrnonymy accordingly, so far as evidence could be obtained, and it develops that several of the names that have been used as names of species in America become untenable on account of having been used earlier as names of species in the Old World.

Macquart's studies in the subfamily in general preceded those of Walker, but since the former writer used a number of names that have been employed by older writers, he made some synonyms which must give way to names which Walker gave to the same species, and a similar condition exists in reference to the work of the later authors.

In his treatment of the Asilinae Lundbeck has followed Mik in reference to the method used in referring to the color and the arrangement of the bristles of the legs. When these organs are stretched out at right angles to the body, the side which looks forward is anterior. As this answers all purposes and is in use it is adopted in this paper.

I have received encouragement in this work from most of the dipterists of the United States and take this opportunity to express my appreciation of their good will. For the loan of specimens, without which I could not have hoped to attempt this paper, I am under obligations to the following museums and private parties: The United States National Museum, including an abundance of material collected by Coquillett on the Pacific Coast; the Francis Huntington Snow Collection of Kansas University; the collection of the Massachusetts Agricultural College and the collection of the University of Illinois. Chas. Dury, Chas. W. Johnson, Dr. O. A. Johannsen, Dr. C. F. Adams, Dr. W. A. Nason, Franklin Sherman, Jr., Dr. O. S. Westcott, S. A. Rohwer, H. S. Harbeck, and Dr. Nathan Banks have loaned or given me specimens from their orn private collections or from the collections of the institutions which they represent. Furthermore Dr. W. D. Hunter, of the Bureau of Entomology, Washington, D. C., has sent for study a large collection of Asilinae collected during the time the studies of the cotton-boll weevil and other species have been in progress in Texas. 


\section{LIST OF THE SPECIES.}

Group Asilus.

sericeus Say, Jour. Acad. Sci. Phil., III, 48. Compl. Works II, 63. Wiedemann, Auss. $Z_{w}$. I, 429. Williston Trans. Am. Ent. Soc. XI, plate II, figure 10. Kan. Univ. Quar. II, 68. Riley Mo. Rept. II, 123. Harris. Ins. Inj. Veg. 605.

herminius Walker, List II, 410.

midas Brauer, Sitzungsb. Kaiserl. Akad. Wissensch. XCI, 387, plate II, figure 1. Williston, Kan. Univ. Quart. II, 69. Osten Sacken, Biologia, Diptera I, 209.

Group Rhadiurgus.

leucopogon Williston, Kans. Univ. Quart., II, 75.

cacopilogus new species.

Group Philonicus.

arizonensis Williston, Kan. Univ. Quart. II, 76.

fuscatus new name.

obscurus Hine, Ohio Naturalist VII, 117. Name preoccupied.

limpidipennis new species.

arizonensis as determined by Hine, Ohio Naturalist VII, 116.

rufipennis Hine, Ohio Naturalist VII, 117.

truquii Bellardi, Saggio II, 52. Van der Wulp, Tijdischr. v. Ent. XXV, 116.

Williston, Biologia, Diptera I, 328.

taeniatus Bellardi, Saggio II, 55. Synonymy by Williston.

plebeius Osten Sacken, Biologia, Diptera I, 209. Synonymy by Williston. tuxpanganus Bellardi, Saggio appendix 22. Hine, Ohio Naturalist VII, 118.

Group Nigrasilus.

nitidifacies Hine, Canadian Ent. XL, 202.

Group Antiphrisson.

astutus Williston, Kans. Univ. Quart. II, 70.

lecythus Walker, List II, 451.

Group Eutolmus.

femoralis Macquart, Diptera Exot. Supplement II, 45.

Group Machimus.

avidus Van der Wulp, Tijdschr. v. Ent. XII, 82.

occidentalis new species.

tenebrosus Williston, Biologia, Diptera I, 328.

griseus Hine, Ohio Naturalist VII, 29.

Group Neoitamus.

affinis Williston, Kan. Univ Quart. II, 73.

coquillettii new species.

brevicomus new species.

orphne Walker, List II, 456.

auceps Van der Wulp, Tijdschr. v. Ent. XII, 84.

aeneobarbus Loew. This name was sent to Osten Sacken in a letter and: so far as I can find, no description was ever written.

distinctus Williston, Kansas Univ. Quart. II, 73.

terminalis new species.

flavofemoratus new name.

flavipes Williston, Kansas Univ. Quart. II, 72. Name preoccupied.

Group Stilpnogaster.

auriannulatus Hine, Ohio Naturalist VII, 29.

Group Heligmoneura.

angustipennis new species.

latipennis new species. 
willistoni new name.

\section{Group Cerdistus.}

angustifrons Williston, Kansas Univ. Quairt. II, 71. Name preoccupied. auricomus new species.

piceus new species.

montanus new species.

albicomus new species.

lepidus new species.

antimachus Walker, List II, 454.

\section{Group Tolmerus.}

callidus Williston, Kansas Univ. Quart. II, 75.

delusus Tucker, Kansas Univ. Sci. Bull. IV, 92.

johnsoni new species.

maneei new species.

notatus Wiedemann, Auss. Zw. I, 451. Williston, Kansas Univ. Quart. II, 74. ale thes Walker, List II, 454 .

novæ-scotiae Macquart, Dipt. Exot. Suppl. II, 46. Williston, Kansas Univ. Quart. II, 68.

paropus Walker, List II, 455.

prospectus Tucker, Kansas Univ. Sci. Bull. IV, 94.

prairiensis Tucker, Kansas Univ. Science Bull. IV, 93.

annulipes Macquart, Dipt. Exot. I, 2, 149. Name: preoccupied.

sadytes Walker, List II, 453 .

tibialis Macquart, Hist. Nat. Dipt. I, 313. Name preoccupied.

snowii new name.

annulatus Williston, Kansas Univ. Quart. II, 7C. Name preoccupied.

erythocnemius new species.

\section{Group Epitriptus.}

Group not determined.

gracilis Wiedemann, Auss. $Z_{w}$. I, 445. Osten Sacken, Catal. 235, note on the type.

auratus Johnson, Proc. Icad. Nat. Sci. 1895, 305.

californicus new species.

mesae Tucker, Kansas Univ Sci. Bull. IV, 92.

rubicundus new species.

\section{KEY TO THE SPECIES.}

1. On each side of the abdomen near the incisures with a transverse row of bristles which are clearly larger than the hairs to be seen

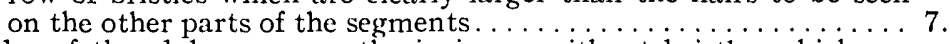

Sides of the abdomen near the incisures without bristles which are clearly larger than the hairs of the other parts of the segments... 2.

2. Large, bright colored species, wings distinctly colored all over..... 3 .

Smaller, modest colored species, wings pale colored or hyaline..... 4.

3. Body and legs uniformly black, wings uniformly rich yellowish

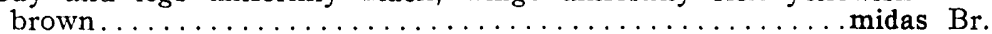

Body brown, legs pale brown, wings brown with the veins margined

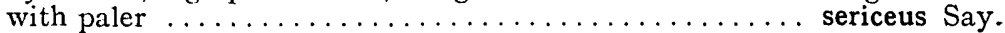

4. Scutellum with more than a dozen long bristles on its margin, female genitalia with a circlet of strong spines at the tip ..........

Scutellum with not more than half a dozen long bristles, female genitalia not with a circlet of spines at the tip...............

5. Upper forceps of the male genitalia protruding half their length beyond the lower forceps................... leucopogon Will.

Upper forceps of the male genitalia about equal in length to the

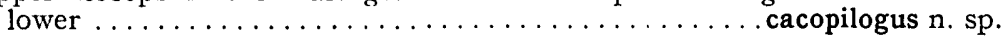

6. Body black, space between the antennae and the facial gibbosity largely shining black....................... nitidifacies Hine

Body brown, face entirely clothed with yellowish dust.......astutus Will. 
7. Ovipositor short, conical, with four spines on the upper side at the apex, upper forceps of the male genitalia excavated on the apical part so that when viewed from above there is a distinct open space

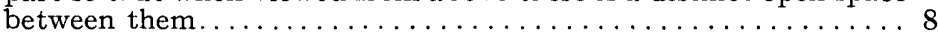

No spines at the tip of the ovipositor ..................

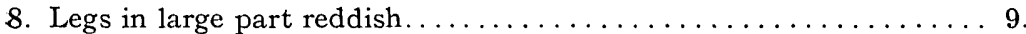

At least the femora of all the legs black....................

9. Largest species falling under 7 , wings smoky, legs dark red, abdomen pure black banded with gray.................... arizonensis Will.

Smaller species, wings hyaline or reddish, abdomen gray black band-

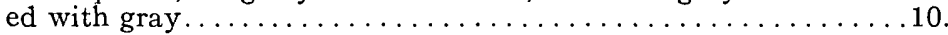

10. Wings limpid, legs pale reddish, brown of fuscus in places.

limpidipennis $\mathrm{n} . \mathrm{sp}$.

Wings reddish, legs pale reddish, usually black in places........11.

11. Legs rather slender, anterior side of each femur in large part black, upper forceps of the male genitalia with the angle at the beginning of the excavation produced inward and backward so that it meets and crosses its fellow of the opposite side.............truquii Bell

Legs rather thick, each femur black except at the tip of the anterior side, angle of the upper forceps not produced........ rufipennis Hine

12. Legs, except the extreme bases of the tibiae, black.....tuxpanganus Bell. Tibiae and tarsi in large part reddish.............. fuscatus $n$. name.

13. Arista of the antenna about twice as long as the third antennal segment, legs almost entirely pale reddish.............. gracilis Wied.

Arista at most only a little longer than the third antennal segment,

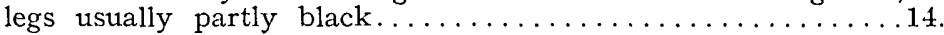

14. Four or more bristles on the margin of the scutellum, ground color of the abdomen, except in one species, clear black............

Normally two bristles on the margin of the scutellum. These bristles may be variable to the extent of having one or two additional smaller ones in an occasional specimen of a species.........23.

15. Wings glassy hayline, legs in part bright yellow, Sixth and seventh segments of the female abdomen shining black, that is, included in

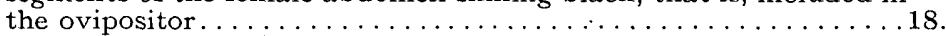

Wings partly brownish, legs in part pale reddish. Sixth and seventh segments of the female abdomen not included in the ovipositor. .16.

16. Dark gray species with gray posterior margins to the abdominal segments. Posterior margin of the eighth ventral abdominal segment produced and furnished with a dense tuft of coarse hairs......

occidentalis $\mathrm{n}$. $\mathrm{sp}$.

Black species. Posterior margin of the eighth ventral abdominal segment not produced and not furnished with a tuft of hairs....17.

17. Shining black species with golden posterior margins to the abdomi-

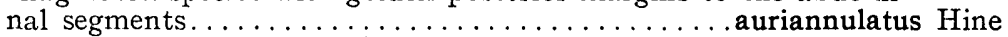

Rather dull black species with gray posterior margins to the abdomi-

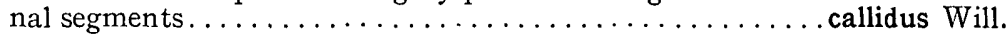

18. Hairs of the face, mystax, bright yellow. Male forceps notched

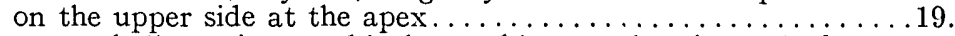

Mystax wholly or in part black or white, or else the male forceps not notched on the upper side at the apex...............

19. All the femora black. . . . . . . . . . . . . . . . . . orphne Walker Front and middle femora almost entirely yellow............. affinis Will.

20. Front and middle femora yellow, each with a black stripe on the upper side......................flavofemoratus $n$. name All the femora black, at most with only a preapical band yellow . . 21.

21. Male forceps notched on the upper side at the apex..........22. Male forceps not notched on the upper side at the apex.... terminalis $n$. sp. 
22. Dorsum of the thorax for its entire length with a crest of long

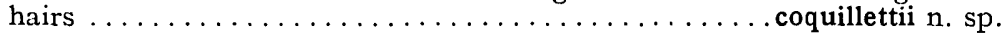

Dorsum of the thorax with the hairs on the anterior part distinctly shorter than on the posterior part.............. brevicomus $n$. sp.

23. From dorsal view male forceps wider at two thirds their length than at their base. First segment of the female ovipositor, that is, the eighth abdominal segment longer than the sixth and seventh

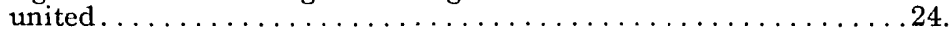

From dorsal view male forceps gradually narrowed from near the base to the apex. First segment of the female ovipositor of normal length, not so long as the sixth and seventh segments united..31.

24. Male forceps distinctly wider than the abdomen at the middle of its

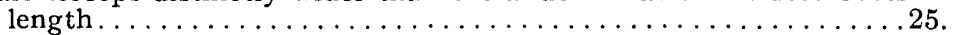

Male forceps not wider than the abdomen at the middle of its length . .26.

25. Wings narrow, male genitalia more than two millimeters in width

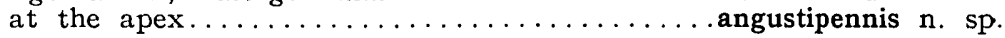

Wings wide, male genitalia less than two millimeters in width at

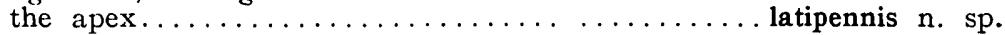

26. Mystax golden, usually with a few black bristles above. Preapical bristles of the abdominal segments pale yellow, male wings not distinctly brown at middle..................

Mystax gray with some bristles above, or if the mystax is not gray, the wings of the male are distinctly brown at middle, preapical bristles of the abdominal segments gray ...................

27. Wing of the male distinctly brown at the middle of the length.....28.

Wing in both sexes hyaline, or very faintly tinged with reddish all over 29.

28. General color black. Viewed from above the male genitalia on each side evenly curved to the apex................ lepidus $n$. sp.

General color brown. Viewed from above the male genitalia on each side quite suddenly contracted just before the apex.......

willistoni $n$. name.

29. Facial gibbosity small, not reaching half way to the antennae, wings hyaline ......................... montanus $n$. sp.

Facial gibbosity large, reaching more than half way to the antennae. . 30 .

30. Body gray, legs red, wings faintly tinged with reddish, bristles and hairs of the body white..................

Body black, legs dark, wings very faintly smcky, bristles of the thorax and legs mostly black................ piceus $n$. sp.

31. Wings clear hyaline, rather large species, upper forceps of the male genitalia split at the tip........................

Wings washed or spotted with gray at the apex and along the posterior border, species of variable sizes, upper forceps of the male

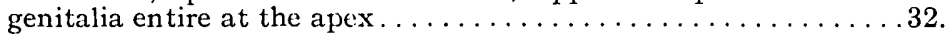

32. Very small species; antennal arista very short, not over one fourth the length of the third segment and not distinctly differentiated from this segment.......................

Larger species, antennal arista distinctly differentiated from its

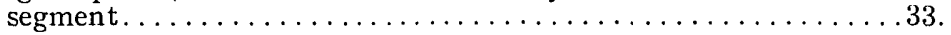

33. Arista of the antenna about as long as the third segment, only two bristles in addition to the apical bristles on the front side of the hind tibia. These bristles are not entirely uniform but may be

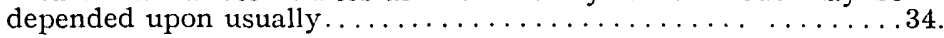

Arista of the antenna usually not over two thirds as long as the third segment, three bristles on the front side of the hind tibia....44. 
34. Gray of the wings in the form of spots in the cells at the apex and along the posterior border, leaving the veins margined with

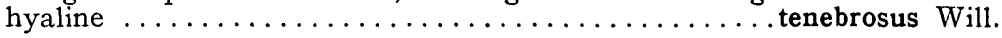

Apex and posterior border of the wing uniformly gray. In some species this coloring is very feint....................

35. Ventrally the posterior margin of the eighth abdominal segment of the male is somewhat produced................ avidus v. d. Wulp.

Ventrally the posterior margin of the eighth abdominal segment is

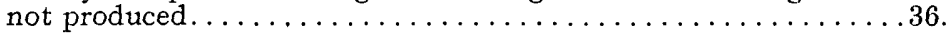

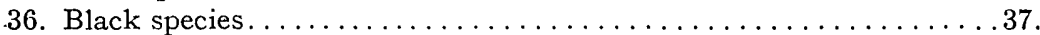

Gray, brown or yellowish brown species...............

37. Small species, legs black, at most with just a trace of reddish on the base of each tibia ......................... maneei $n$.

Larger species. Legs plainly marked with red............... 38 .

38. Male upper forceps long, usually longer than the last three abdominal segments together. Mystax largely black............sadytes Walker

Male upper forceps shorter, usually about as long as the first two abdominal segments together. Mystax largely light........39.

39. Eastern species. Each tibia red on basal third........... notatus Wied.

Western species. Each tibia largely red, especially on the posterior

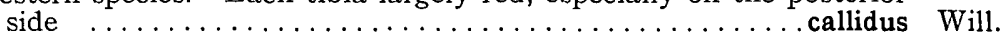

40. Rather large species, wings wide, end lamellae of the ovipositor

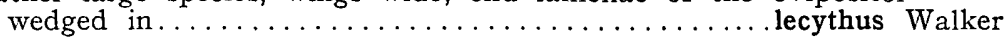

End lamellae of the ovipositor not wedged in . . . . . . . . . 41 .

41. All the femora wholly black..............novae-scotiae Macquart

Femora partly red, at least each with a preapical red band.......42.

42. Femora variable, sometimes wholly red, commonly with only the posterior side red, mystax almost always white or yellowish white. 43 .

Femora largely black, mystax in large part black, from side view male genitalia widest at two thirds the length...... erythocnemius $n$. sp.

43. Small reddish species, mystax straw yellow, legs mostly red, male genitalia red...........................

Larger species, mystax white, occasionally a few black bristles above, male genitalia black. ................... antimachus Walker.

44. Small reddish species, legs red, at most only the anterior side of each femur slightly darkened, male genitalia red.......... rubicundus $n$. $s p$.

Femora in large part black. Species of ordinary size. . . . . . . . . 45 .

45. Each femur with a preapical band and the posterior side red......46.

Each femur with only a preapical band red................

46. Dull gray species, under side of each front femur with numerous gray hairs $\ldots \ldots \ldots \ldots \ldots \ldots \ldots \ldots \ldots \ldots \ldots \ldots \ldots \ldots \ldots \ldots \ldots \ldots$ delusus Tucker

Bright gray or yellowish species, under side of each front femur with

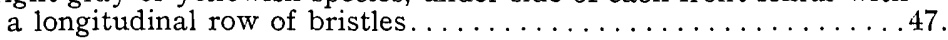

47. Thorax with a very distinct mid-dorsal black stripe which reaches its entire length, male genitalia dark red..............johnsoni $n$. sp.

Mid-dorsal thoracic stripe not very distinct and abbreviated behind. Male genitalia black, or at least dark fuscus....... prairiensis Tucker.

48. Under side of each front femur furnished with abundance of rather long hairs, not in rows ...................... snowii n. name.

Under side of each front femur with a row of bristles...........49.

49. Bristles on the under side of each front femur white and rather weak. Upper forceps of male genitalia from side view widest at two thirds

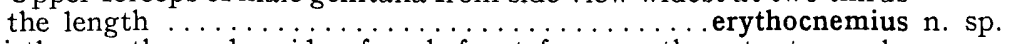

Bristles on the under side of each front femur rather stout, nearly always partly or wholly black, upper forceps of the male genitalia from side view of the same width throughout.......... paropus Walker 
Asilus gracilis Wiedemann. (Figs. 1 and 2.)

A long slender species with yellow body and legs, facial gibbosity very small, mystax composed of a few white bristles. Length 15-17 millimeters.

Head rather large, face and front narrower than usual; palpi and proboscis dark, the former clothed with light hair; first two segments of the antenna yellow, third brown, first segment longer than the second, arista near twice as long as its segment; occipito-orbital bristles largely yellow, although in some specimens these are nearly all black. Facial gibbosity hardly evident, mystax composed of a dozen or so light colored hairs and bristles. Thorax yellow, thinly clothed with gray dust, mid-dorsal stripe dark brown; wings hyaline with a slight clouding at the apex and along the posterior border; legs pale, anterior side of each femur, apex of each tibia and of each tarsal segment usually darker, although there is quite an amount of variation in the color of the legs. Abdomen somewhat darker than the rest of the body, nearly uniformly colored but with narrow band on the posterior border of each segment a little lighter; these narrow bands are each preceded by about four yellow bristles on either side of the abdomen. Male upper forceps short, rounded at the tip, of nearly the same width throughout; lower forceps dropped so that there is always a distinct space between the upper and lower; end lamella of the oviduct style-like.

Specimens from North Carolina, Texas, Florida, and Georgia. The type of Asilus auratus has been studied and is this species without question. The long antennal arista makes the species easy of identification.

Asilus lecythus Walker (Figs. 3 and 4).

Asilus femoralis Macquart is this same species but as there is an older Asilus femoralis by Zeller from Europe, Isis 1840, 49, 3, Walker's name must be used.

Color yellowish brown; femora largely black but each with preapical band and often with the posterior side yellow, tibiae and tarsi in large part yellow. Length 18-21 millimeters.

Face and front covered with pale yellowish dust; facial gibbosity prominent, mystax composed of a few black hairs above and numerous pale yellowish hairs below, beard pale, palpi and proboscis black, the former with light colored hairs; antennae largely black but apex of second and base of third joints plainly yellow; first two segments together equal in length to the third which is of nearly the same length as its arista. Occipito-orbital bristles black and yellowish, somewhat variable; other bristles and hairs of the occiput light colored. Thorax dull gray on the sides, more yellowish above, mid-dorsal brown stripe divided anteriorly; wings largely hyaline, apical portion and posterior border slightly clouded; coxae colored like the sides of the thorax, femora variable, in some specimens black with the exception of the preapical band; in others, the whole posterior side yellow, even the different femora of the same specimen may vary in coloration; tibiae 
yellow each with a narrow black apex, metatarsi yellow apex of each black; other tarsal segments black mostly with yellow bases. Abdomen dark brown in ground color, thinly clothed with yellowish dust; posterior margin of each segment plainly lighter colored than the other parts and preceded on each side by a few bristles. End lamella of the oviduct wedged in.

This is the only American species known to me with the end lamella of the oviduct wedged in. Specimens from Pennsylvania, New Jersey, Maryland, North Carolina, Massachusetts, Maine, Ohio.

Asilus tenebrosus Williston (Fig. 5).

Machimus griseus Hine, The Ohio Naturalist VII, 29, is a synonym. There is an older Asilus griseus Wiedemann from Java, Dipt. Exot. I, 192,17 .

Male and female brownish gray with reddish legs and narrow white margins at the apexes of the abdominal segments. Wings hyaline with well defined dark markings in the cells at the apex and along the posterior margin. Length 17 to 20 millimeters.

Front and face of usual width, facial gibbosity prominent extending two thirds of the distance from the oral margin to the antennae; mystax black above and white below; antennae black, rather long, third segment of each with its style decidedly longer than the other two segments combined, style about equal in length to the remainder of the segment, beard white. Thorax dark in ground color but clothed with gray dust which is denser in some places than in others, thus giving the part a variegated appearance; a wide mid-dorsal black stripe divided anteriorly by a narrow grayish interval; scutellum with two black bristles at the apex; legs red with numerous black bristles, coxae black, each femur dark on the anterior side except just before the apex; wing clear hyaline with dark markings as follows: marginal, both submarginal and first posterior cells each with a stripe which reaches the apex of its respective cell; second posterior, discal and anal cells each with an angular spot not contiguous with the margin of the wing; halteres pale yellowish. Abdomen of the same general color as the thorax, with a light colored annulation preceded by a row of white bristles at the apex of each segment. Eigth segment of the male distinctly produced below, but not with an appendage as in some of the European species of the group; male genitalia reddish in color, oviduct shining black.

Several specimens from southwestern Colorado and Huachuca Mountains, Arizona; Flagstaff and Williams, Arizona, collected by H. S. Barber; White Mountains, New Mexico, by Townshend; Pecos and Beula, New Mexico, the latter place at an elevation of 8000 feet, by Cockerell.

The hyaline wings with the dark colored markings in the cells as described and the wide male genitalia are sufficient to separate the species from its near relatives. 
Asilus avidus Van der Wulp (Fig. 6).

General color reddish gray, abdomen darkest and with prominent gray margins to each of the segments above; eighth ventral segment of the male slightly produced posteriorly but with only a few bristly hairs on its margin. Preapical band and usually the posterior side of each femur and the tibiae and tarsi dark recdish. Length 15-18 millimeters.

Facial gibbosity rather prominent. With black bristles above and yellowish gray bristles below; each antenna black, third segment exclusive of the arista scarcely as long as the other two, arista hardly as long as the third segment; beard white; occipito-orbital bristles yellowish gray with the exception of three to five black bristles behind the upper part of each eye. Thorax gray with the usual dark markings above, bristles of the posterior part prominent and black, about four black bristles on the margin of the scutellum. Legs clothed with fine hair and prominent bristles; the hair is either white or yellowish but the bristles are black; each coxa and the anterior side of its femur black, otherwise each leg is reddish, slightly darker in some places than in others. Wing hyaline with a slightly darkened tinge at the apex. Abdomen rather dark but appearing yellowish gray from certain angles; narrow posterior margin of each segment plainly gray, margin of the eighth segment below in the male plainly produced and forming a distinct angle but not with so prominent a tuft of hairs as in occidentalis.

Several specimens from Copeland Park and North Boulder Creek, near Boulder, Colorado, the latter part of August and the first part of September, 1907. Collected by S. A. Rohwer and Glen M. Hite. Also from Beula, New Mexico, $800(0)$ feet elevation, by Cockerell.

Everything considered this is most like Van der Wulp's species. The tibiae are most plainly red at base but nowhere is there a sharp differentiation of colors as in most specimens of occidentalis. The male genitalia are nearly straight, and in this respect quite different from those of occidentalis. The latter character more than any other has led to the determination of this species as avidus.

Asilus occidentalis n. sp. (Fig. 7).

General color gray with the thorax often yellowish gray. In some specimens each femur has a preapical reddish band, in others this is not the case. Posterior margin of the venter of the male eighth abdominal segment furnished with a dense cluster of rather long bristly hairs. Length $14-18$ millimeters.

Facial gibbosity prominent, mystax largely black but with a number of yellowish hairs below; face clothed with yellowish dust, beard white; each antenna black with the third segment exclusive of the arista slightly longer than the first two segrnents together, arista scarcely as long as the third segment. Occipito-orbital bristles mostly black, but in some specimens nearly all yellow. Thorax gray or yellowish gray, median darker markings not especially prominent, scutellum with at least four bristles on its margin. Legs dark, each femur 
may or may not have a preapical reddish band; each tibia plainly reddish at the base and this color is not always well defined below and may extend nearly the whole length, especially on the upper side; tarsi black although the metatarsi are often largely reddish; wings hyaline with the apex and the inner margin of each faintly gray. Abdomen dark, differing slightly according to the angle from which it is viewed, posterior margin of each segment plainly gray.

Specimens are at hand from British Columbia collected by Harvey, Venables and R. S. Sherman; Ormsby County, Nevada, by C. F. Baker; several counties in southern California by Coquillett; also from Eldorado County, California, and from Oregon and Washington:

The fact that the male genitalia are bent upward near the middle as shown in the figure, serves to designate the species. It is much like Asilus notatus of the eastern states but in the male the extension of the ventral margin of the eighth abdominal segment with its dense tuft of long hairs, is distinctive and in both sexes the form of the third antennal segment is a useful character. In occidentalis this antennal segment is plainly wider than in notatus.

Asilus auricomus n. sp. (Figs. 8 and 9 ).

General color yellowish gray, mystax largely composed of golden yellow bristles, also, yellow bristles before the incisures of the abdominal segments. Legs yellow with an elongate black marking on the anterior side of each femur and a black spot at the apex of each tibia. Length 15 millimeters.

Front and face rather narrow and covered with yellowish gray dust. Facial gibbosity rather prominent, reaching half way to the antennae, furnished with yellow bristles intermixed above with a few black ones. Beard gray, occipito-orbital bristles yellowish gray. Antennae black, third segment of each exclusive of the arista about equal in length to the other two; arista decidedly longer than the third segment. Thorax yellowish gray with the usual dark markings; scutellum clothed all over with rather long yellow hairs and with two yellow bristles on the margin. Wings hyaline on the basal part, and grayish at the apex and along the inner margin. Legs largely shining yellow; coxae dark, clothed with gray dust and yellow hairs; each femur with an elongate black marking on the middle of the anterior side; each tibia with a black spot at the apex of the anterior side; tarsi infuscated, especially on the apical part of each segment; pulvilli yellow. Abdomen yellowish gray with yellow hairs on the segments and several yellow bristles on each side before the incisures. Male appendages, viewed from above, widest near the apex; each appendage black on the basal part and yellowish distally.

Several specimens of both sexes from Medina County, Ohio, taken in August. Others from Iona, N. J., collected by E. Daecke, New Haven, Connecticut, by R. L. Butrick, southern Illinois by C. A. Hart, and from Germantown, Pa. 
Asilus piceus n. sp. (Figs. 10 and 11).

Nearly black species with hyaline wings and brown legs. Length 15 to 17 millimeters.

Facial gibbosity not very prominent, reaching half way to the antennae, mystax composed of black and white hairs, intermixed, beard white, occipito-orbital bristles largely black, face and front clothed with gray dust, antennae black, third segment exclusive of the arista near the length of the other two, arista equal to the third segment in length. Thorax brown in ground coior, clothed with gray or yellowish gray dust, mid-dorsal stripe rather wide, black, split on the anterior part and abbreviated behind; wings clear hyaline in both sexes, veins brown; legs brown with light colored hairs and with light and dark bristles. Coxae colored like the thorax, anterior sides of all the femora, apexes of all the tibiae and the last four segments of each tarsus darkened more or less. Abdomen black, posterior margins of the segments narrowly gray, male forceps distinctly excavated at the upper corner of the apex, first segment of the oviduct nearly as long as abdominal segments five, six and seven; apical segment stylelike and near the length of abdominal segment seven.

Specimens from Amherst, Massachusetts, from the collection of the Massachusetts Agricultural College.

Asilus montanus n. sp. (Figs. 12 and 13).

Rather small, slender, gray species with hyaline wings, largely reddish legs, very small facial gibbosity and mystax composed of a few bristly hairs which are mostly white, although there are a few black ones above. Length 13 millimeters.

Face clothed with gray dust; palpi and protioscis black, the former with white hairs; occipito-orbital row of bristles with a few black ones back of each eye, otherwise all the bristles and hairs of the occiput white. Thorax gray, mid-dorsal stripe black, divided before and abbreviated behind; several black bristles on the posterior part, two black bristles on the margin of the scutellum. Wings clear hyaline; legs reddish, anterior side of each femur, apex of each tibia and each tarsal segment fuscous. Abdomen clothed with grayish dust, most pronounced on the posterior margins of the segments. These margins are preceded on each side by two or three small bristles. Forceps of the male shining brownish black, each upper with a distinct angle on the dorsal side at about four fifths of the length.

This species is entirely distinct from its relatives on account of its small facial gibbosity and the few bristles composing the mystax. The male genitalia are distinctive also.

A male collected by Cockerell at Alpine Tavern, Mount Lowe, California, at an altitude of 5,000 feet. Taken August 12th. Type in the United States National Museum. 


\section{Asilus albicomus n. sp. (Fig. 14).}

Medium sized gray species with red legs and hyaline wings in both sexes. Bristles of the whole body, except a few on the feet and in the extreme upper part of the mystax, white. Length 13 to 15 millimeters.

Facial gibbosity prominent reaching nearly half way to the antennae. Mystax composed of many light hairs, only a few dark ones above; bristles and hairs of the occiput light colored; thorax gray with the usual dark markings above; wings hyaline in both sexes; legs red, femora a little darker anteriorly than posteriorly; each abdominal segment with a gray posterior margin preceded by a row of white bristles which reach nearly over the dorsum, especially forward.

Both sexes taken by H. K. Morrison in Montana. Type male and female in the United States National Museum.

Asilus lepidus n. sp. (Figs. 15 and 16).

Dark colored species, facial gibbosity prominent, mystax composed of numerous hairs, femora largely black, especially on the anterior sides; tibiae mostly reddish, wings in the female hyaline, in the male infuscated, especially on the posterior half. Length 15 millimeters.

Facial gibbosity prominent, mystax composed of numerous hairs, black above, light below; antennae black; thorax clothed with gray dust leaving the usual markings on the dorsum nearly bare, black bristles on the posterior part above, scutellum with two black bristles cn its margin. Wing in the female clear hyaline, in the male somewhat infuscated especially beyond the branching of the second and third veins, and somewhat along the veins of the basal part of the wing. Legs with femora black anteriorly and dark reddish posteriorly, tibiae dark reddish, apex of each darkest, metatarsi largely red, other tarsal segments mostly fuscous. Abdomen black, each segment above with a prominent gray border which is preceded by a row of bristles which nearly reaches over the dorsum of the insect, especially forward.

Male from Colorado. Female from the White Mountains of New Mexico, about 6800 feet elevation, collected July 23, by Townsend. Types in the United States National Museum.

Asilus willistoni n. n. (Figs. 17, 18 and 19).

New name for Asilus augustifrons Williston, which is preoccupied by Asilus augustifrons Loew from Asia Minor, Linn. Ent. (1849) IV, 126,64 .

Rather large grayish brown species with brown legs and narrow front and face, wings of the male more or less dark from the base of the first submarginal cell, of the female nearly clear hyaline. Length 15 to 20 millimeters.

Head of medium size; front and face narrow, clothed with dust which varies in different specimens from gray to golden, facial gibbosity prominent, mystax composed of a large number of hairs, which are black above and white, or sometimes golden, below. Antennae black, first two segments nearly equal in length and together about as long as the third which is of nearly the same length as the arista. 
Beard gray; occipito-orbital bristles gray as are all the hairs of the occiput. Palpi and proboscis black, the former with gray hairs. Thorax gray, often with a yellowish tinge above, mid-dorsal stripe black. Wings yellowish in the male quite dark from the base of the first submarginal cell, especially along the costal border; in the female the wings are much lighter than in the male and in some specimens these are practically hyaline. Legs brown, femora somewhat variable but usually distinctly darker anteriorly, tibiae darkened at the apexes, tarsal segments mostly dark, but the first on each leg lighter except at the apex. Abdomen brownish black; on the posterior margin of each segment is a white band which is preceded by a row of white bristles which are largest anteriorly. Male forceps black and shining, upper forceps swollen, thickest beyond the middle of their length, oviduct long and slender but not including the seventh abdominal segment.

The description and drawings were taken from the type specimens which are in the Francis Huntington Snow collection of the University of Kansas. Other specimens from western Washington collected by H. K. Morrison, Vernon, B. C., by E. P. Venables, Goldstream, B. C., by R. V. Harvey.

\section{Asilus auriannulatus Hine.}

General color shining blue-black with uniform pale brown wings and black and yellow legs. The second, third and fourth segments of the abdomen each with a golden yellow annulus at the apex. Length $1 \pm$ to 17 millimeters.

Front and face rather narrow, the latter covered with golden yellow pollen between the callosity and the antennae, callosity slightly elevated, mystax black, beard white, third segment of the antenna about as long as the other two together, style shorter than the remainder of the segment; thorax lark in ground color, clothed with pollen which is denser in some places than in others, mid-dorsal stripe opaque black, narrowly divided on the anterior part; scutellum with several black bristles at its apex; wing uniformly pale brown all over with a slight intensity of coloration on the margin of the second vein near the middle of its length. Legs black and yellow, a preapical ring on each femur, all the tibiae except at apexes and bases of the tarsal segments yellow, other parts black; hind femora somewhat variable in that the yellow is likely to increase at the expense of the: black; halteres yellow. Abdomen shining blue-black, second, third and fourth segments each with a golden yellow annulus at apex not preceded by a row of bristles; eighth segment below not widened but furnished with a conspicuous tuft of erect hair. Genitalia of both sexes shining black, of the male somewhat wider than the abdomen when viewed from above and about as long as the seventh and eighth segments combined.

Several specimens of both sexes taken in the Hope Mountains of British Columbia by R. V. Harvey and R. S. Sherman of Vancouver, during the first part of July. Also from Kalso, B. C., collected by R. P. Currie, western Washington, by H. K. Morrison, Humboldt County, California, by H. S. Barber, and from several other places in California and Washington. 
Asilus angustipennis n. sp. (Figs. 22 and 23).

Dark species, ground color somewhat obscured by a thin covering of yellowish dust, wing rather wide, whitish hyaline on the basal part, brownish beyond the branching of the second and third veins, especially near the costal border. Length $16-18 \mathrm{~mm}$.

Head rather large, front and face narrow and clothed with golden dust, facial gibbosity rather prominent but not reaching more than half way to the antennae, mystax composed of numerous bristles which are black above and yellow below, beard not abundant, fine and yellowish white in color; palpi, antennae and proboscis black; posterior orbits clothed with pale bristles and hairs. Thorax clothed with yellow dust and black bristles and hairs, the usual black mid-dorsal stripe divided before, and some blackish spots on either side; scutellum with two yellow bristles on its margin and numerous short light colored hairs on its disk. Wings hyaline at the base but quite distinctly darkened on the outer half, this darkening is most pronounced along the costal margin before the small cross vein. Legs black and reddish; base apex and posterior side of each femur, most of each tibia and bases of the tarsal segments reddish; coxa, trochanter, most of the anterior side of each femur, apexes of tibiae and tarsal segments black; many of the bristles of the legs are light, although there are some black ones. Abdomen clear brown, each segment with a narrow apical band of pale yellowish preceded on either side by some light colored bristles. Male genitalia thickened and much wider than the rest of the abdomen.

A male taken by R. S. Woglum, at Highlands, North Carolina, in September, 1906, and sent in by Franklin Sherman, Jr. Also a male from St. Elmo, Virginia, taken by F. C. Pratt, September 13th. The latter specimen is in the U. S. National Museum.

Asilus latipennis n. sp. (Figs. 24 and 25).

Rather dark in color, hairs and bristles of the body mostly yellow. Length 15-17 millimeters.

Facial gibbosity rather small, mystax yellowish below, black above, beard yellowish gray, face above the gibbosity rather narrow and clothed with golden dust; antennae, palpi and proboscis black, third antennal segment about as long as the other two, arista about the length of its segment, bristles and hairs of the occiput mostly pale yellow. Thorax clothed with yellowish gray dust, with a wide middorsal stripe and two spots on either side dark brown. Legs black and yellow with black bristles and yellow hairs, femora largely black in some specimens, more or less yellowish in others, in all cases observed the hind femora are yellow at the base; all the tibiae are yellow with narrow black apexes, base of each first tarsal segment yellowish, otherwise the tarsi are brown. Wing in the male wide, whitish hyaline on the basal third, lightly clouded with brownish from thence to the apex, region of the stigma plainly brown. Wing of the female hyaline, only obscurely clouded at the apex. Abdomen thinly clothed with brown dust, posterior margin of each segment yellow, 
and preceded on either side by several yellow bristles. Male genitalia rather short, swollen, distinctly wider than the abdomen, shining black in color; oviduct long and slender, about equal in length to segments 5,6 and 7 .

A male from Ithaca, New York, collected by Nathan Banks, August 10,1889 , and a male and female from Montgomery, Massachusetts, collected by Knab, August 24, 1896.

Asilus affinis Williston (Fig. 26).

Mystax of the male bright golden. Legs bright yellow with the exception of the posterior femora which are black. Length 15 to $16 \mathrm{~mm}$.

Facial gibbosity prominent, mystax composed of abundant golden hair. Occiput with dark hairs above and pale hairs below. Thorax black, thinly clothed with dray dust, on the dorsum with numerous dark more or less bristly hairs; wings hyaline; legs largely yellow, each middle femur with a black marking above on the basal half, each hind femur and apex of each hind tibia on the outer side also black. Abdomen shining black, apex of each segment with a narrow gray border. Male forceps wide, excavated on the upper side at the apex.

The male type from which my description and drawing were taken are in the Francis Huntington Snow Collection at the University of Kansas. This specimen is from the state of Washington. Another male taken in the Santa Cruz Mountains of California by Coquillet is in the U. S. National Museum.

Asilus flavofemoratus n. n. (Fig. 27).

New name for Asilus flavipes Williston which is preoccupied by Asilus flavipes Wiedemann from Europe, Syst. Beschr. (1820) II, 325,28 .

Shining black, front and middle femora yellow with the exception of an elongate black marking above on each, hind femora black, all the tibiae yellow. Length 12-18 millimeters.

Face and front narrow, facial gibbosity prominent, but not reaching near to the antennae, mystax of the female composed of a few black hairs above and several white ones below, of the male almost entirely black, but sometimes partially golden and there may be other variations. Wings hyaline, very slightly gray at the apex and along the posterior margin. Each femur of the forward and middle legs with a black stripe above, hind femora black; all the tibiae yellow, each posterior black at the apex on the outer side; each metatarsus yellow with a black apex, other tarsal segments mostly black. Abdomen shining black, apex of each segment narrowly gray; upper forceps of the male entire above and of about the same width throughout.

Specimens at hand from Pa., Ohio, N. J., Va., Mass., N. Y., Ills., N. C., Md. and Canada. Common in the eastern part of the United States. 
Asilus orphne Walker (Fig. 28).

A black species and in large part shining. Mystax golden, all the tibiae bright yellow and all the femora black. Wings hyaline. Length 12-19 millimeters.

Face narrow, covered with golden dust; facial gibbosity prominent and extending nearly to the antennae, mystax usually golden in color but varying to pale yellowish, composed of many slender bristly hairs; palpi and proboscis black, the former clothed with black hairs; occiput with black hairs above and pale ones below. Thorax black, thinly clothed with gray dust, hairs of the sides gray, of the dorsum mostly black; wings hyaline, very faintly gray at the extreme apex and along the narrow posterior border. Femora shining black, each front one usually yellow at the apex, each tibia and metatarsus yellow, black at apex, other tarsal segments largely black. Abdomen black, narrow margin of each segment above gray, clothed with gray hairs which are most abundant towards the base.

Commonly taken in the territory from Maine to Illinois and from Canada to North Carolina. Specimens also are at hand from Colorado and from Montana.

Walker's description of orphne fits the female of this species well. Dr. Johannsen agrees with me in identifying auceps. There is no doubt but that the species under consideration is distinctus and it is my opinion that this latter is the same as orphne, as is aeneobarbis which is a name sent by Loew in a letter to Osten Sacken without description. The name is sufficient to characterize the species however, when it is known that Loew's specimens were from the eastern United States. .

Asilus coquillettii n. sp. (Fig. 29).

Black, all the femora black, all the tibiae in large part yellow. A prominent crest formed of black bristly hairs extends the whole length of the thoracic dorsum. In the region covered by this paper no other species has such a crest. Length 13-16 millimeters.

Facial gibbosity elongate and prominent and reaching nearly to the antennae. Mystax composed of an abundance of rather fine long hairs which are all black in the female and black on each side and otherwise white in the male. Front in both sexes with numerous long erect black hairs; antennae black, first two segments of each usually hairy; palpi black with black hairs; lower part of the occiput with some gray hairs otherwise with black hairs. Thorax thinly clothed with yellowish dust, a crest of long black bristly hairs on the middle of the dorsum reaches from the anterior part to the scutellum which also is furnished with numerous similar hairs. Wings hyaline; in the male each forward leg has the femur black, the tibia yellow with a narrow black apex, tarsus yellow with the exception of the fifth segment and its claws which are black; middle leg the same; hind leg black with the exception of a little more than basal half of the tibia which is yellow; in the female the legs are similar but the front and middle tarsi have the black including the apex of the first segment 
and nearly all of the other segments. Abdomen shining black with narrow gray margin to each of the segments.

In some respects this species resembles affinis but the extreme hairiness of the head and thorax is characteristic, while there is a distinct difference in the color of the legs and a certain amount of distinction in the male genitalia.

Males and females collected by Coquillett in Santa Clara County, California. Types in the United States National Museum.

Asilus terminalis n. sp. (Fig. 30).

Gray dust on the thorax more dense than most species of this section of the genus, mystax in both sexes black around the outside, middle part pale yellowish, upper forceps of the male genitalia not excavated on the dorsal side at the apex. Length 14-17 millimeters.

Facial gibbosity prominent, long but not reaching the antennae, mystax in both sexes black above and below and with a row of black bristles on either side, thus the pale yellowish central hairs are entirely surrounded with black; palpi black with black hairs; antennae black, first two segments with rather short black hairs; beard white, vestiture of the upper part of the occiput black. Thorax with a covering of gray dust which largely obscures the black ground color, dorsum in front with short and posterior part with longer black hairs; scutellum with a number of long black bristly hairs on its margin and with numcrous shorter black hairs on its disk; wings hyaline; front leg in both sexes with tibia and metatarsus, except the apex of each, and bases of the other tarsal segments reddish yellow, other parts black but in some specimens the apex of the femur may be narrowly yellow; middle leg the same, except there is slightly more reddish yellow at the apex of each tibia and metatarsus, and the femora are entirely black in all cases; hind leg black except a little more than the basal half of the tibia which is reddish yellow. Abdomen black with a narrow gray posterior margin to each segment and in the female especially each segment is partially gray on either side. Upper forceps of the male genitalia not very wide, about the same width throughout, rounded at the distal end but not excavated at the apex of the dorsal side as in all other western species of the same section of its genus.

Although this species is not striking in appearance its male genitalia mark it as entirely distinct from other known western species.

The male and female from San Antonia Canyon, near Ontario, California collected July 25, 1907.

Asilus brevicomus n. sp. (Fig. 31).

Black, middle portion of the mystax in the male white, otherwise black, in the female wholly black, hairs of the whole body decidedly shorter than in coquillettii. Length $15-17$ millimeters.

Facial gibbosity long and prominent, in the male the mystax above and below and a row of bristles on either side black, middle portion white, in the female all black; front, and first two segments of the antennae furnished with short black hairs, occiput with black hairs above and white ones below. Thorax with short black bristly hairs 
on the anterior half and longer ones on the posterior half. Wings hyaline, anal angle in the male with a small white area. Front leg with the apex of the femur, tibia and metatarsus except the apex of each, and the bases of the other tarsal segments yellow, otherwise black; middle leg similar but the femur is entirely black; hind leg black except three fourths of the tibia which is yellow. Abdomen shining black with a very narrow posterior margin to each segment gray. Upper forceps of the male appendages shining black, of nearly the same width throughout, superior side distinctly excavated at the apex.

The species is easily separated from affinis by the black forward and middle femora and from coquillettii by the very much shortened vestiture especially on the anterior half of the thorax.

Both sexes from Kalso, B. C., sent in by Harvey and Sherman, and a female from Los Angeles county, California, collected by Coquillett.

Asilus sadytes Walker.

This is the same as Asilus tibialis Macquart, which is preoccupied by A. tibialis Fabricius, Ent. Syst. (1793) IV, 383, 30; A. tibialis Fallen from Europe, Dipt. Suec. Asil. (1814) 9, 4; A. tibialis Wiedemann from Russia, Zool. Mag. (1817) I, 2, 29. There are at least two other species that have been described under A. tibialis, one from the Cape by Macquart himself and the other by Gimmerthal from Russia. Both of these latter have been named since the North American insect.

Black, abdomen with white border to each segment, femora black, tibiae and metatarsi largely reddish. Male forceps large and distinctly longer than abdominal segments six, seven and eight. Length 13-17 millimeters.

Face and front clothed with white dust, facial gibbosity prominent, mystax with numerous black hairs above and few white or pale yellowish ones below, although the distribution of black and light hairs varies through a series of specimens; antennae black, first two segments longer than the third which is about equal in length to its arista. Proboscis and palpi black, the latter with black hair. Beard white, occipito-orbital bristles black, remainder of the vestiture of the occiput white. Thorax rather thinly clothed with gray dust which has a yellowish tinge above, mid-dorsal stripe black; wing hyaline, apex and posterior margin slightly clouded; coxae colored like the thorax, femora black, tibiae largely reddish but usually with black markings on the outside, variable in a series of specimens; each metatarsus reddish with brown apex, other tarsal segments black or brown, each reddish at the base. Abdomen black with white posterior border to each segment. Male forceps large and longer than abdominal segments six, seven and eight.

Specimens are at hand from Ohio, Ind., N. Car., Mass., N. Y. and. $\mathrm{Pa}$. The species is common in sections of Ohio where I have collected in August. 
Asilus notatus Wiedemann.

Black species. Legs black except the extreme base of each tibiae. Length 14-18 millimeters.

Face and front clothed with gray dust, facial gibbosity prominent, mystax with a few black hairs above and numerous pale yellow or white hairs beneath; beard white; occipito-orbital bristles mostly black, other bristles and hairs of the occiput white; proboscis and palpi black, the latter with black hair. Thorax mostly clothed with gray dust although the thorax has a yellowish cast; nid-dorsal stripe black, split anteriorly; wings hyaline, slightly clouded at the apex and along the posterior border; the legs are black except the narrow base of each tibia which is reddish; there is some variation in the legs, the reddish of the tibiae may be more extensive than indicated and the metatarsi may be reddish either wholly or in part. It is quite characteristic for this species to have areas of close lying golden pile, especially on the lower sides of the tibiae and metatarsi. Abdomen black, each segment narrowly white posteriorly. Upper forceps of the male genitalia small and short as compared with those of sadytes.

N. Y., N. J., D. C., Mass., Ct., Ills., Canada, Ind., Mo., Kan., Pa., Me. and Ohio.

\section{Asilus callidus Williston.}

Black, each abodminal segment with an apical white band, preapical band of each femur, each tibia and each metatarsus largely brown. Length 1j-18 millimeters.

Facial callosity prominent, mystax black above and pale yellow or white below. Face and front clothed with gray dust, beard white; palpi and proboscis black, the former with black hair. Occipitoorbital bristles variable but always partially black and in some cases almost wholly black, other hairs and bristles of the occiput pale yellow. Thorax clothed with gray dust, mid-dorsal stripe black, narrowly divided anteriorly. Coxae colored like the thorax; femora black each with a preapical brown band; tibiae brown, each darker on part. of the anterior side and at the apex; tarsal segments largely black, each brown basally or in case of the metatarsus brown except at the apex. Wing hyaline, clouded at the apex and along the posterior border, veins dark colored. Abdomen black, each segment with a white posterior border; male forceps in large part clothed with pale yellow hairs, rather suddenly curved at the tip, shorter than abdominal segments six, seven and eight.

Specimens from British Columbia and Washington.

\section{Asilus novae-scotiae Macquart.}

Dark brown body with plain black femora and yellow tibiae. Length 14-18 millimeters.

Face and front of ordinary width and clothed with yellow dust, facial gibbosity rather prominent, mystax composed of black hairs above and yellowish hairs below, but in some specimens the entire mystax is composed of light colored hairs; antennae black, third segment rather narrow and of the same length as its arista; occipito-orbi- 
tal bristles mostly black above and yellowish at the sides, beard white. Thorax furnished with yellow dust, mid-dorsal stripe dark, narrowly divided anteriorly. Legs to the tips of the femora pure black, tibia yellow with black tips, metatarsi mostly yellow, other tarsal segments black, each with a narrow yellow base. Abdomen brown with narrow, light colored posterior margin to each segment. Male forceps about as long as abdominal segments six, seven and eight, oviduct shining black, first segment equal in length to abdominal segments six and seven, apical segment slender and style like.

The species is distributed, at least, from North Carolina to Canada and most specimens have been taken near the Atlantic coast, although there are records for Ohio.

Asilus antimachus Walker.

A light brown species with clear white mystax and with the legs almost wholly reddish. Length 16-20 millimeters.

Face and front clothed with gray dust. Facial gibbosity rather prominent, mystax and beard white; in some specimens there may be a very few black hairs just above the oral opening and once in a great while a specimen may be found that has a few short black hairs in the extreme upper part of the mystax; palpi and proboscis black, the former with black hair; some of the occipito-orbital bristles may be black but most of the hairs over the whole occiput are white; antennae black; first two segments together plainly longer than the third which is somewhat shorter than its arista. Thorax clothed with gray dust on the sides, and with yellowish dust above, mid-dorsal stripe and some spots on either side dark brown. Wings hyaline with slight coloring at apex and along the posterior border. Coxae colored like the sides of the thorax, femora largely red in most specimens, but varying from one having a small elongate black spot on the anterior side to one largely black with a wide preapical band; tibiae yellow, each with the apex narrowly black or brown, metatarsi yellow, each with a black tip; other tarsal segments black, some at least with yellow bases. Abdomen dull grayish brown, posterior margin of each segment lighter but the contrast between the segment and its margin not so pronounced as in novae-scotiae.

Common in various sections of Ohio in late summer. Specimens also from Indiana, Kansas, Virginia and Missouri. In the locality of Akron, Ohio, the species is abundant on weeds and in the pastures during the greater part of August.

Asilus maneei n. $\mathrm{sp}$.

A small black species with black legs, gray stripes and markings on the thorax and gray posterior borders to the abdominal segments. Length 10-12 millimeters.

Facial gibbosity rather prominent, mystax composed of a mixture of gray and black hairs, face and front black but sparsely clothed with gray dust, beard white, occipito-orbital bristles black, proboscis and palpi black, the latter with black hair. Thorax black, largely covered with gray dust, the mid-dorsal stripe black but distinctly divided 
by a white interval; legs black with not more than a suggestion of reddish at the bases of the tibiae, coxae with white hair, femora with some white hair and black bristles, other parts of the legs with short black hairs and prominent black bristles; wings hyaline, faintly gray at the apex and along the posterior border. Abdomen black with rather long gray hairs especially toward the base, and with the posterior border of each segment gray. The male appendages shining black, rather slender, elevated on distal half and about; as long as abdominal segments six, seven and eight together. Oviduct shining black, distinctly compressed laterally, end lamella free and style like.

This species must have somewhat the appearance of Asilus anonymus Williston, from Mexico, but there are only two bristles on the margin of the scutellum, the third antennal segment is of about the same length as its arista, and there are other differences

A male and female taken in couple at Southern Pines, North Carolina, May 15, 1908, by A. H. Manee for whom the species is named.

\section{Asilus delusus Tucker.}

Gray brown. Preapical band and the posterior side of each femur red. Under side of each front femur with numerous rather long white hairs. Length $16-18$ millimeters.

Mystax with numerous white hairs below and a few black ones above. Occipito-orbital bristles mostly black above, white on either side; thorax gray brown, mid-dorsal black stripe well defined, bristles on the posterior part prominent and black. Wing hyaline, clouded at the apex and along the posterior border. Front femur with the anterior side black, preapical band and the posterior side red; tibiae and tarsi mostly red, each tibia with a stripe on the anterior side and the apex dark, apex of each tarsal segment brown; middle leg the same; hind leg similar but the dark coloring of the tibiae more suffused. Abdomen gray brown, narrow posterior margin of each segment plainly gray.

Specimens from Kansas and Montana, those from Kansas being the types.

This was described as a variety of annulipes Macquart by Tucker whose identification of annulipes conforms to specimens called snowii in this paper, as I have determined by a study of the specimens used by Tucker. I agree that delusus is related to snowii but has a distinct general color over the entire body, the posterior side of each femur red and the third antennal segment shorter than in that species with the arista two thirds as long as the segment which bears it.

Asilus johnsoni n. sp. (Figs. 32 and 33).

Body bright yellowish, femora black outwardly, otherwise legs largely red, wing reddish, hyaline along many of the veins. Mid-dorsal stripe of the thorax prominent, brown and reaching the scutellum in nearly its entire width. Male genitalia uniformly red. Length 17-21 millimeters.

Facial gibbosity not especially prominent, mystax composed of a number of rather long pale yellow bristles below and a few shorter 
black ones above; antennae black, third segment about as long as the first two together, arista more than half as long as its segment; occipitoorbital bristles coarse, black, beard colored like the mystax. Thorax with a distinct brown mid-dorsal stripe, bristles of the posterior part of the thorax black and rather prominent; tip of the scutellum with two black bristles. Front leg with the anterior side of the femur black, preapical band and the posterior side red; tibia red, marking on the anterior side and the narrow apex dark; tarsal segments sometimes wholly red but often each is dark at the apex; middle and posterior legs like the anterior ones. Wing reddish, margins of the veins in large part hyaline. Abdominal segments without distinct lighter posterior margins; male genitalia shining reddish, upper forceps rather small, narrow and straight from side view.

Males and females taken at Folson, Delaware County, Pennsylvania, July 7,1893 , by Charles W. Johnson for whom the species is named.

\section{Asilus snowii n. $\mathrm{n}$.}

New name for Asilus annulatus Williston, which is preoccupied by A. annulatus Fabricius from East Indies, Syst. Ent. 1775, 794, 12; A. annulatus Macquart from France, Dipt. du Nord 1826, 36, 16.

A rather large dark brown species. Each femur with the exception of the preapical band, black; tibiae more or less distinctly annulate with black; under side of each front femur provided with numerous rather long hairs. Length 15-20 millimeters.

Mystax with black bristles above and white or pale yellowish ones below; antennae black, third segment long and rather slender, arista usually not over half the length of its segment. The row of occipitoorbital bristles mostly black, although in some specimens part of them are yellow. Thorax clothed with yellowish dust and with the usual markings and bristles above; wing in large part clouded with reddish, especially at the apex and along the posterior border, there is a tendency for many of the veins to be margined with hyaline, even in the clouded area. Each femur with a preapical reddish band, front and middle tibiae each with an annulus near the middle and the apex black, each metatarsus in large part yellow, black at the apex, other tarsal segments mostly black, usually narrowly yellowish at base; hind tibiae in large part infuscated, but a narrow basal space is always yellowish and there appears to be more or less variation in the extent. of the black in a series of specimens. Abdomen clothed with dust so as to give it a dark brown color, posterior margins of the segments only slightly lighter.

Specimens are at hand from Canada, N. H., Mo., Penn., N. Y., Mass., Ills., Kansas and Ohio.

The type of annulatus is in Philadelphia and Mr. E. T. Cresson, Jr., through the kindness of Dr. Skinner, has compared specimens for me. 


\section{Asilus prairiensis Tucker.}

A light brown species, preapical band and the posterior side of each femur brown. Front femur with close lying hair and several distinct bristles in a longitudinal row on the under side. Length 14-20 millimeters.

Mystax yellow with the exception of a very few short black hairs above, occipito-orbital bristles yellow, as are most all of the bristles of the whole body; third segment of the antenna long, nearly twice the length of its arista. Anterior femur with a red preapical band and posterior surface, otherwise black; tibia dark at the middle, especially on the anterior side and at the apex; metatarsus nearly entirely red, other tarsal segments mostly black; middle leg like the front one; hind leg the same except the dark color of the tibia is more suffused. Wing with the apex and the posterior margin faintly clouded, otherwise hyaline. In some specimens the hyaline tends to follow the margins of the veins into the clouded area. Abdomen. yellowish brown, the gray posterior margins of the segments not very plainly marked.

Specimens are at hand from Kansas, Colorado, New Mexico and Texas.

This species in the southern states appears to occupy about the same position as paropus at the North. Macquart's description of annulipes from Carolina does not apply well to any of the robber-flies known to me from the northern states, especially is this true of the words "Cuisses fauves, brunatres en dehors," but does apply to the present species. These is an older Asilus annulipes by Brulle from Europe, so the name is not tenable for the American insect. With a large series of specimens before me showing quite a range in size and to some extent in coloration, the conclusion is reached that Tolmerus prairiensis Tucker is the same and being the name next available becomes the name of the species.

\section{Asilus paropus Walker.}

A medium sized species, femora entirely black with the exception of a reddish preapical ring; Wing reddish although hyaline along the veins of the disk and the base. Front femur with distinct bristles below. Length 13-17 millimeters.

Facial gibbosity prominent, mystax composed of numerous bristly hairs which are mostly pale but there are a very few black ones above. Antennae black, or at most only narrowly yellow at the apex of the second and the base of the third segments; occipito-orbital bristles in large part yellow but variable; in a pair taken in couple, these bristles are black in the female and yellow in the other sex. Thorax thinly clothed with yellowish dust and with the usual markings above, short black hairs anteriorly and long black bristles posteriorly. Wings distinctly reddish, most of the veins of the disk and toward the base plainly margined with hyaline. Front leg with the femur, except a preapical band, middle and apex of the tibia, narrow apex of the metatarsus and all except the extreme bases of the other tarsal segments black or infuscated, otherwise yellowish; middle leg like the 
front one; hind leg similar but the tibia except a narrow base may be wholly infuscated. Specimens are before me in which all the tarsi are black and the light color of the tibiae is much encroached upon by the same. Front femur with close lying hairs and a row of distinct bristles on the under side. Abdomen thinly clothed with yellowish dust, posterior margin to each segment rather obscurely gray.

Specimens are at hand from N. H., Mass., Colo., N. M., Wyo., Toronto, Can., Ct., N. Y., Ills., Ind. and Ohio.

The species is somewhat variable in size and appearance, but I take it to be fully distinct. Walker's description fits quite well here and prospectus is likely a synonym.

Asilus rubicundus n. sp. (Figs. 20 and 21).

Uniformly reddish, mystax pale yellowish, bristles and hairs on all parts of the body light colored. Length 12 millimeters.

Face and front rather wide and clothed with yellow dust, facial gibbosity not very prominent, mystax pale yellowish, beard white, antennae dark, second segment lighter than the others, third segment about the length of the other two, arista near the length of its segment. Occipito-orbital bristles yellow. Thorax yellowish red with a wide darker mid-dorsal stripe; legs red, outer side of each femur and apex of each tibia slightly darkened; wings small, hyaline, only a slight clouding at the apex and along part of the posterior border. Abdomen yellow, two or three light bristles on each side before each of the incisures; genitalia red, upper forceps of the male quite wide at the tip and evenly rounded.

Specimens of this small and distinct species have been taken at Onaga, Kansas, by Crevecoeur in June and July, and in southern Illinois, near Carbondale, also in the same months. The latter specimens are in the Illinois state collection of insects at Urbana.

\section{Asilus mesae Tucker.}

Very small species, clothed with pale yellow dust, bristles of the body and legs, all light colored. Genitalia in both sexes red. Antenna with a very short arista which is hardly differentiated from its segment. Length 8-12 millimeters.

Facial gibbosity small, mystax composed of pale bristles, antenna black, the third segment is characteristic for instead of having the usual differentiated arista this segment gradually tapers to the apex, occipito-orbital bristles pale yellow. Ground color of the thorax hidden by a coating of yellow dust, wings small and hyaline, slightly clouded at the tip. Femora usually black but variable; tibiae reddish each darker at the apex, tarsi mostly dark, although each metatarsus usually is reddish on the basal part. Posterior margin of each abdominal segment narrowly light colored. Genitalia red.

Usually the small size of this species will lead to its recognition, but it may be confused with rubicundus, from which its antennae will readily distinguish it.

Specimens are at hand from Colorado, Wyoming and Kansas. The types are in the Francis Huntington Snow Collection. 
Asilus erythocnemius n. sp.

Dark brown species, each femur except a preapical band black, other parts of the legs largely red. Third antennal segment rather wide, arista almost as long as its segment, nearly all the bristles of the body and legs black. Length 11-14 millimeters.

Facial gibbosity reaching about half way to the antennae, mystax composed mostly of pale yellow bristles although there are a few short black ones above, occipito-orbital bristles black, beard white. Thorax clothed with yellow dust, but with a distinct black mid-dorsal stripe. Wing hyaline, slightly clouded at the apex and along the posterior border; femur of each leg black with the exception of a preapical band which is red; each tibia red, usually with a dark marking near the middle of the anterior side, apex also dark; metatarsi red, other segments mostly black. There is a tendency in some specimens for the hind tibia to be darkened more or less leaving only a narrow band at the base yellow, especially is this coloring apt to show on the anterior side. Front femur with a row of rather weak white bristles on the lower side. Abdomen colored like the thorax, two or three small bristles on either side before the incisures; from side view the upper forceps of the male genitalia widest at about two thirds the length, lower side nearly straight.

Specimens from Mass., N. Y., Ct., N. J., Kan., Mont., Colo., Md., Wyo. and Ohio.

\section{Asilus astutus Williston (Fig. 35).}

Yellowish brown species, form rather robust, femora black anteriorly, preapical band and posterior side red. Thorax and legs with black bristles. Antennal arista about one third as long as the segment which bears it. Length 15 millimeters.

Facial gibbosity most prominent just above the oral opening, gently sloping to the level of the face about half way to the antennae. Mystax mostly pale yellow but with several black. bristles above, beard pale yellow; antenna black, third segment distinctly longer than the first two together, arista about one third as long as the third segment. Occipito-orbital bristles straw yellow. Thorax clothed with yellow dust, mid-dorsal stripe dark brown and distinctly split on the anterior part. Wing in large part clouded, base and disk largely hyaline. Each femur black anteriorly with a preapical red band, red posteriorly; front femur with a few black bristles beneath; each tibia dark anteriorly with a narrow red base, posterior side red; tarsal segments red, each more or less darkened apically. Abdomen clothed with yellowish brown dust, posterior margins of the segments not distinctly lighter; no bristles before the incisures. In the type male specimen before me only seven abdominal segments are visible. Genitalia rather small and red.

The types are in the Francis Huntington Snow Collection and are labelled as coming from California. There are no other records of the ofcurrence of the species known to me. 
If Loew's names were used this species would come in Antiphrisson without any question. The form and color taken in connection with the male genitalia which are figured in the plate, and the absence of bristles before the margins of the abdominal segments make the species rather easy of determination.

Asilus californicus n. sp. (Fig. 36).

Dark colored species, wings clear hyaline, legs mostly yellow, preapical bristles of the abdominal segments light colored, upper forceps of the male genitalia split at the apex. Length 21 millimeters.

Face and front of usual width, facial gibbosity prominent, mystax with a row of rather fine black bristles around the outside, remainder composed of coarser white bristles; palpi black with light hair; antenna black, third segment about as long as the first two together, arista not quite as long as its segment; bristles and hairs of the occiput light with the exception of a few rather strong bristles just back of the upper part of each eye. Thorax dark gray, mid-dorsal stripe black but divided by a distinct gray interval. Wings clear hyaline and wider than usual; front femur black on the anterior side for the basal half of its length, otherwise yellow; tibia yellow, narrowly black at the apex; metatarsus yellow, other tarsal segments black; middle leg like the anterior with the addition or black at the tip of the anterior side of the femur; posterior leg the same as the middle one except that the black of the femur takes the form of a stripe not reaching either end. Abdomen dark gray, posterior margin of each segment only slightly lighter and preceded by a prominent row of yellow bristles. Male genitalia shining black with numerous long black bristly hairs especially beneath; upper forceps rather long, of nearly the same width throughout, apex split with the lower division the longer and curved inward.

A male of this distinct species from Cisco, California, altitude 5,000 feet, taken in June, 1901, and received from Charles W. Johnson.

\section{Asilus sericeus Say.}

A large brown species with brown wings and pale brown legs. Length 20-28 millimeters.

Facial gibbosity with the most prominent point on a level with the lower edge of the eye, mystax composed entirely of yellow bristles, palpi black with black hairs, first and second segments of the antennae yellow, third segment black and decidedly longer than the first two together, arista about one fourth as long as its segment; bristles and hairs of the occiput all yellow. Thorax clothed with bright yellow dust, mid-dorsal stripe dark brown, reaching the scutellum in its full width; wings brown, veins margined with paler; legs pale brown, each femur usually with a dark marking on the anterior side. Abdomen colored like the thorax, no bristles before the incisures.

Generally distributed over the eastern part of North America from Canada to Texas and at least as far west as Kansas. 
Asilus midas Braucr.

Entire body and legs velvety black, pulvilii on all the feet pale brown, hairs and bristles everywhere black except in the male there is a tuft of white hairs on each cheek below the eye. Wings rich brownish yellow all over. The species cannot be confused with any of the others of its subfamily. Brauer called attention to its close resemblance to a species of Midas from the same locality in Mexico where the type was taken.

Specimens from New Mexico and from Oak Creek Canyon, Arizona, taken in August by Dr. F. H. Snow are in the museum of the University of Kansas at Lawrence.

\section{Asilus nitidifacies Hine (Figs. 37 and 38 ).}

Black, wings slightly fumose, face just beneath the antennæ shining black; female with conical oviduct. Length, 12 to $15 \mathrm{~mm}$.

Facial gibbosity rather prominent, and clothed with black bristles above and white bristles below; face just beneath the antennae shining black, otherwise clothed with gray dust, which is most pronounced along the entire margins of the eyes; third segment of the antenna rather narrow and a little longer than the first two together, arista only about half as long as its segment, beard white; occipito-orbital bristles all black. Ground color of the thorax black, but thinly covered with gray dust, four to six black bristles on the margin of the scutellum; wings slightly fumose, almost hyaline on basal parts. Femora all black, with fine white hair and black bristles; tibiae and tarsi more or less dark red, approaching black in parts. Hind tibiae each with three or four black bristles on the front side near the middle. Abdomen black above, with gray hind borders to the segments, but not preceded by bristles that differ from those on the other parts of the abdomen.

A male specimen collected in the Hope Mountains of British Columbia by R. S. Sherman, July 16, 1906, and a female collected on Vancouver Island, July 2, 1903, by R. V. Harvey. Also specimens in the United States National Museum from Mt. Hood, Oregon, taken by H. K. Morrison.

\section{Asilus cacopilogus n. sp.}

Gray, wings rather narrow and hyaline. Upper forceps of the male genitalia not protruding beyond the other part, which is terminated by a distinct pencil of long white hairs. Length 15-18 millimeters.

Facial gibbosity not prominent, mystax composed of numerous white bristles, antennae, palpi and broboscis black, palpi and first two segments of each antenna with black hair, otherwise bristles and hairs of the whole head white, third antennal segment distinctly shorter than the first two together, rather wide, arista. fully as long as its segment, front and face clothed with gray dust. Thorax gray, above with two brown stripes on the anterior part; legs largely black, base and apex of each femur and basal half or more of each tibia reddish, the posterior side of each may be partly or entirely reddish, and there 
are other variations in the extent of the black and reddish of the legs in the specimens at hand; claws and pulvilli long and quite slender. Wings hyaline, posterior branch of the third vein bent slightly forward at the middle of the length beyond the furcation and then backward just before the margin of the wing. Abdomen dark, thinly clothed with gray dust and numerous gray hairs which are longest at the sides. Ovipositor black with a circlet of spines at the tip; male genitalia rather short, superior part not protruding beyond the other part which is tipped with a pencil of long white hairs.

Specimens from Rosser, Texas, taken by F. C. Pratt; Clark County, Kansas, by F. H. Snow; Anglesia, New Jersey, by H. S. Harbeck, Havana, Illinois, and from Admore, Oklahoma; Fromont, Nebraska, and from other places in Texas besides the one mentioned. It appears to be more eastern in distribution than leucopogon.

This name was carried by some specimens in the Francis Huntington Snow Collection but I cannot find that any description has ever been published.

\section{Asilus leucopogon Williston.}

Light gray, wings hyaline, scutellum sparsely clothed all over with rather long white bristles, male genitalia with the superior part protruding at least half its length beyond the inferior part which is without the pencil of hairs present in cacopilogus. Length 15-18 millimeters.

Face and front broad, clothed with nearly white dust, facial gibbosity most prominent just above the oral opening, gradually sloping to the level of the face slightly below the insertion of the antennae, mystax composed entirely of white bristles. Antenna black, third segment shorter than the first two together, arista about as long as its segment, palpi and proboscis black, the former with black hair; beard white, occipito-orbital bristles white or very pale yellowish. Thorax gray, mid-dorsal brown stripe not conspicuous, wings rather narrow and hyaline; legs in large part red, each femur on the anterior side with a black marking which varies in extent in different specimens; each tibia infuscated toward the tip. Abdomen darkened somewhat and often with distinct gray posterior margin to each segment. Oviduct usually shining black, but reddish in part in some specimens, male genitalia usually red, superior part extending beyond the inferior part for about half its length.

Professor Aldrich has kindly sent me a pair of this species from the material which Williston had when he wrote the original description.

Specimens are at hand from Pierre, South Dakota; from Morton County, Kansas, and Bill Williams Fork, Arizona, collected by F. H. Snow. A number of specimens collected by myself near Tombstone, Arizona, August 5, 1907, are larger than the others and distinctly more reddish in color but present no structural differences. 
Asilus arizonensis Williston (Figs. 39, 40 and 41).

Ground color of the body dull black, posterior margin of each abdominal segment plainly yellowish gray, wings uniformly fumose, legs reddish. Length 16 to 19 millimeters.

Gibbosity of the face small, clothed with white bristles, sometimes the two uppermost bristles are black; face and front clothed with gray dust. Antennae black, or in some cases partially reddish, first segment of each nearly twice as long as the second, third segment, without the arista, a little shorter than the first two together, arista about equal in length to the third segment; bristles of the rear of the head light colored, although one or two on each side are often black. Thorax clothed with yellowish gray dust, notum with the usual darker areas; wings uniformly light smoky brown; legs reddish in general color, coxae clothed with gray dust and hairs; outer side of each femur, apex of each tibia and all of each tarsus beyond the apical part of each metatarsus infuscated. Abdomen dull black above, posterior border of each segment with a yellowish gray band, sides and venter gray.

The type of this species is in the Francis Huntington Snow Collection. It is a female and is labelled as coming from Arizona. Besides I have studied a male and two females trom southern Arizona and fifteen males and females taken in the Huachuca Mountains of Arizona by myself July 28, 1907. Most of the latter specimens were taken from stones lying at the edge of a small brook where they had stationed themselves to watch for insects they desired for food.

This is the largest North American species of its group so far known. The wing in the type is just a shade lighter than in the other specimens. It is possible that this is due to fading for the specimen appears as if it is fully developed. The species is very easy to identify on account of its large size and almost fumose wings.

In a former paper published in the Ohio Naturalist, I identified the next species as arizonensis, but after studying the type it is evident that that conclusion was wrong. I did not have specimens of the present species when I wrote the paper referred to.

Asilus limpidipennis n. sp.

Gray species with hyaline wings and red legs. Body of the male quite slender, legs distinctly more slender than in arizonensis. Length 17 millimeters.

Gibbosity of the face very small, with a few white bristles; front and face white; bristles and hairs of the head all white; first segment of each antenna black, second more or less yellowish and shorter than the first, third black, exclusive of the arista about as long as the other two together, arista slender and slightly shorter than the third segment. Thorax covered with gray dust with a mid-dorsal dark stripe, narrowly divided before, and two spots on each side, one before and the other behind the transverse suture. These brown markings are not so prominent as in some of the other species of the genus. Wings hyaline, legs largely reddish, coxae colored like the thorax, femora 
with more or less black on the outer side, especially on the apical half; tibiae and metatarsi black at the apexes, other tarsal segments mostly black. Abdomen dull black, before the incisures with narrow white bands, in the front margin of which there are on either side in each two or more bristles.

Male and female taken in south-western Colorado, July 14, 1899, by E. J. Oslar.

In a former paper published in the Ohio Naturalist I identified this species as arizonensis but after studying the type of that species have come to the conclusion that the preceding must bear that name.

\section{Asilus fuscatus n. n.}

New name for Philonicus obscurus Hine which is preoccupied by Asilus obscurus Meigen from Europe, Syst. Beschr. (1820) II, 315, 12.

General color dark with the wings pale fumose all over. The abdomen has different shades according to the angle from which it is viewed. Length 10 to 16 millimeters.

Gibbosity of the face small with a few bristles, part of which are black and the others white; face with gray dust, front with some small black bristles and occiput above with a row of black bristles; antennae black, first segment of each longer than the second, third, exclusive of the arista, about as long as the other two together; arista a little shorter than the third segment. Thorax clothed with brownish gray dust, with a mid-dorsal dark brown stripe narrowly divided before, and on either side two spots of the same color, one before the transverse suture and the other behind it. Wings uniformly darkened all over, but it would not be far wrong to say that they are hyaline. Legs black and reddish; coxae colored like the sides of the thorax, femora entirely black except that the posterior ones are often narrowly yellowish at the extreme base of each; tibiae reddish at the base and black at the apex of each; the extent of the two colors on the tibiae is somewhat variable, the tendency being for the black to be most extensive on the outside and the reddish on the inside; feet with the first two segments of each reddish on basal part, other segments usually entirely black. Abdomen opaque black, before the incisures with gray bands, in the front margin of each of which on either side are two or more distinct bristles.

A male from Kentucky, across the river from Cincinnati, collected by Charles Dury; two females from Washington, D. C.; males and females from Riverton, N. J., and Pendleton, N. C., procured from Mr. Charles W. Johnson; several specimens from New Jersey and Pennsylvania, collected by H. S. Harbeck; also specimens from New York, Massachusetts and Virginia.

\section{Asilus rufipennis Hine.}

General color gray, legs reddish, wings of a uniform reddish color. all over. Length 15 millimeters.

Gibbosity of the face small, furnished with a few bristles which usually are all white, but in one or two of the species studied there is now and then a black bristle mixed with the others; face and front 
with silvery dust; occipito-orbital bristles black; first segment of each antenna black, second large yellowish and shorter than the first, third black, not quite as long as the first two together, arista slender, about the length of the third segment; beard entirely white. Thorax clothed with gray dust but with a mid-dorsal brown stripe narrowly divided before and two spots of the same color on eitrer side, one before and the other behind the transverse suture; coxae gray, usually an elongate blackish spot on the anterior side of each femur and extreme apexes of all the tibiae and the tarsal segments blackish, otherwise legs red. Wings uniformly reddish yellow all over, halteres pale yellow. Abdomen opaque black with a narrow gray band in front of each incisure and in the anterior margin of each of these bands there is on either side two or more bristles.

Specimens from Douglas County, Kansas, taken in May and June by E. S. Tucker. Also a specimen from Havana, Illinois, taken June $9,1905$.

\section{Asilus truquii Bellardi (Figs. 42 and 43).}

Grayish black, wings pale reddish, thorax with a distinct dark middorsal stripe; legs slender, femora mostly black anteriorly. Angle at the middle of the superior side of each part of the male upper forceps produced inward and backward until it meets and crosses its fellow of the opposite side. Length 12 to 14 millimeters.

Facial gibbosity very small, mystax composed of a few bristles, some of the upper ones of which are black and the others white; antennae black, bristles and hairs of the occiput nearly all gray but there may be a couple of black bristles behind either eye. Thorax yellowish gray with a distinct, nearly black mid-dorsal stripe; wings pale reddish all over; legs slender, femora largely black anteriorly, reddish posteriorly; each tibia and metatarsus red, dark at the apex; other tarsal segments in large part black, narrow base of each red. Abdomen gray black with the posterior border to each segment narrowly gray. Oviduct black, short, conical with four spines at the tip above.

Specimens from Mexico taken in August. Bellardi, Osten Sacken and Williston have reported the species from various parts of the same country.

\section{Asilus tuxpanganus Bellardi.}

Rather small dark colored species, legs black except a red interval at the base of each tibia, wings with a slight smoky tinge. Length 11 to 15 millimeters.

Gibbosity of the face small with a few bristles which are black above and white below; face rather narrow and clothed with white dust; each antenna black, first two segments with black hairs, second segment shorter than the first, third slightly shorter than the first two together. Arista slender and a little shorter than the third segment, palpi and proboscis black, beard white. Thorax everywhere clothed with silvery dust, above with two black stripes near the middle of the 
notum and two spots of the same color on either side, one before and the other behind the suture; wings with a slight smoky tinge but this is so faint that they well may be called hyaline and there is no apparent darkening at the apexes as in many species of the subfamily Asilinae. Coxae silvery, extreme base of each tibia reddish, otherwise legs black with black bristles; halteres pale throughout. Abdomen shining black above with narrow white bands in front of the incisures; in the anterior border of each white band there is on each side two or more medium sized bristles, more prominent in the male than in the female; venter of the abdomen silvery and with a few white hairs.

Taken at Gualan, Guatemala, January 13th, and at Mazatanango, Guatemala, February 3, 1905.

\section{EXPLANATION OF THE PLATES.}

FIG. 1. Side view of the male genitalia of Asilus gracilis.

FIG. 2. Side view of the female genitalia of A. gracilis.

FIG. 3. Side view of the male genitalia of A. lecythus.

FIG. 4. Side view of the female genitalia of A. lecythus.

FIG. 5. Side view of the male genitalia of A. tenehrosus.

FIG. 6. Side view of the male genitalia of A. avidus.

FIG. 7. Side view of the male genitalia of A. occidentalis.

FIG. 8. Side view of the male genitalia of A. auricomus.

FIG. 9. Dorsal view of the male genitalia of $A$. auricomus.

FIG. 10. Side view of the male genitalia of A. piceus.

FIG. 11. Dorsal view of the male genitalia of A. piceus.

FIG. 12. Side view of the male genitalia of A. montanus.

FIG. 13. Dorsal view of the male genitalia of A. montanus.

FIG. 14. Side view of the male genitalia of A. albicomus.

FIG. 15. Side view of the male genitalia of A. lepidus.

Fig. 16. Dorsal view of the male genitalia of A. lepidus.

FIG. 17. Side view of the male genitalia of A. willistoni.

FIG. 18. Dorsal view of the male genitalia of A. willistoni.

FIG. 19. Side view of the female genitalia of A. willistoni.

FIG. 20. Side view of the female genitalia of A. rubicundus.

Fig. 21. Side view of the male genitalia of $A$. rubicundus.

FIG. 22. Side view of the male genitalia of A. angustipennis.

FIG. 23. Dorsal view of the male genitalia of A. angustipennis.

FIG. 24. Side view of the male genitalia of A. latipennis.

FIG. 25. Dorsal view of the male genitalia of A. latipennis.

FIG. 26. Side view of the male genitalia of A. affinis.

FIG. 27. Side view of the male genitalia of A. flavofemoratus.

Fig. 28. Side view of the male genitalia of A. orphne.

FIG. 29. Side view of the male genitalia of A. coquillettii.

FIG. 30. Side view of the male genitalia of A. terminalis.

FIG. 31. Side view of the male genitalia of $\mathrm{A}$. brevicomus.

FIG. 32. Side view of the male genitalia of A. johnsoni.

FIG. 33. Side view of the female genitalia of A. johnsoni.

Fig. 34. Side view of the male genitalia of A. erythocnemius.

FIG. 35. Side view of the male genitalia of A. astutus.

FIG. 36. Side view of the male genitalia of A. californicus.

FIG. 37. Side view of the male genitalia of A. nitidifacies.

FIg. 38. Dorsal view of the female genitalia of A. nitidifacies.

FIG. 39. Side view of the male genitalia of A. arizonensis.

FIG. 40. Dorsal view of the male genitalia of $\mathrm{A}$. arizonensis.

FIg. 41. Side view of the female genitalia of A. arizonensis.

FIG. 42. Side view of the male genitalia of $A$. truquii.

FIG. 43. Dorsal view of the male genitalia of A. truquii, 


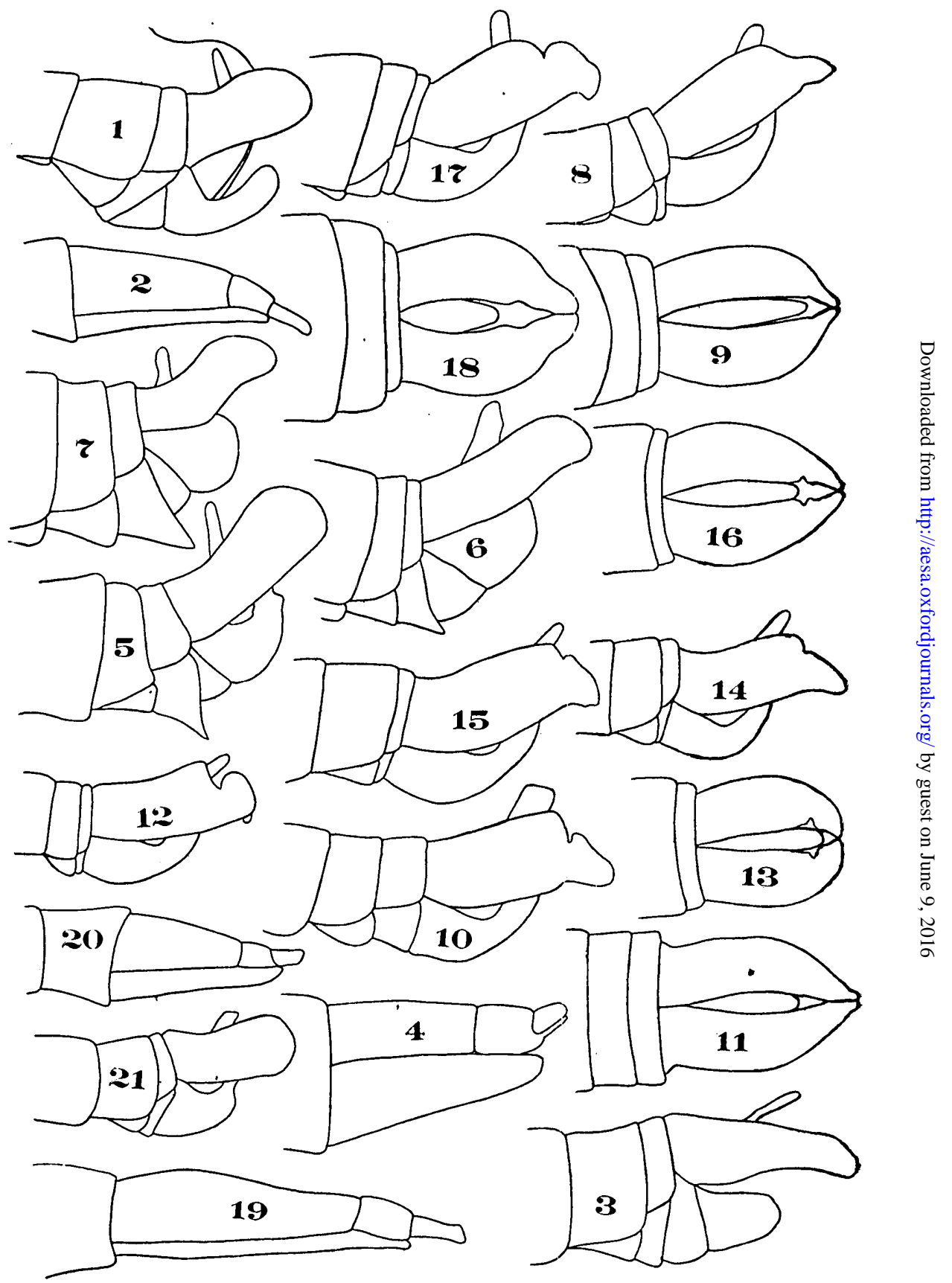

Jus. S. Hine. 


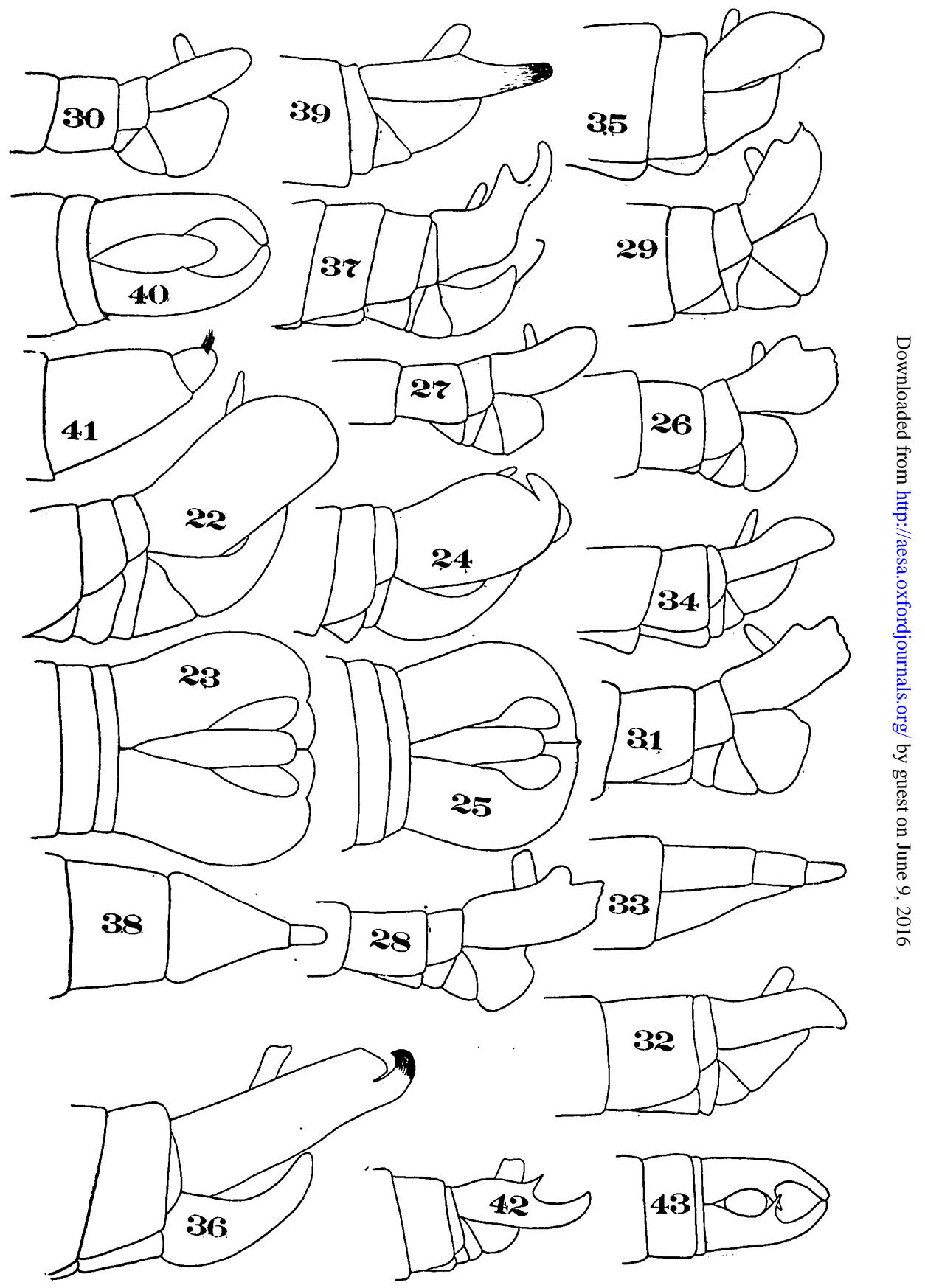

